\title{
GAMBARAN TINGKAT PENGETAHUAN DAN SIKAP PEMANDU WISATA DALAM PENANGANAN GIGITAN KERA DI MONKEY FOREST UBUD
}

\author{
Ni Luh Dian Mirayanti ${ }^{1}$, Putu Ayu Asri Damayanti², Ni Luh Putu Eva Yanti ${ }^{3}$ \\ ${ }^{1}$ Mahasiswa Program Studi Sarjana Keperawatan dan Profesi Ners FK Universitas Udayana \\ ${ }^{2,3}$ Dosen Program Studi Sarjana Keperawatan dan Profesi Ners FK Universitas Udayana \\ Alamat Korespondensi: dianmirayanti16@gmail.com
}

\begin{abstract}
ABSTRAK
Kunjungan wisatawan keMonkey Forest Ubud tergolong tinggi selam 3 tahun terakhir. Kera dapat menggigit dan mencakar ketika merasa terancam sehingga peran pemandu wisata yang menemani wisatawan masuk ke Monkey Forest Ubud sangat penting dalam penanganan dini kasus gigitan kera untuk mencegah timbulnya potensi infeksi berbahaya atau yang dapat mengancamn nyawa. Penelitian ini merupakan jenis penelitian kuantitatif dengan metode deskriptif. Penelitian ini menggunakan pendekatan cross sectional dengan sampel 62 responden yang diperoleh dengan teknik purposive sampling. Hasil penelitian mengenai karakteristik responden adalah $(6,5 \%)$ berusia $17-25$ tahun, $(33,6 \%)$ berusia $26-35$ tahun, $(33,6 \%)$ berusia 36-45 tahun, $(20,7 \%)$ berusia $46-55$ tahun, dan $(4,8 \%)$ berusia 56-65 tahun. Jenis kelamin laki-laki (100\%), pendidikan terakhir SMP $(8,1 \%)$, SMA $(54,8 \%)$, Diploma (25,8\%), strata sarjana $(11,3 \%)$. Sebanyak $(74,25 \%)$ mendapat informasi dari orang lain, dan $(25,8 \%)$ dari media massa. $(6,5 \%)$ responden pernah memiliki pengalaman dalam penanganan gigitan kera dan $(93,5 \%)$ tidak pernah. Gambaran tingkat pengetahuan responden dalam penanganan gigitan kera yaitu (19,3\%) memiliki pengetahuan baik, (56,5\%) memiliki pengetahuan cukup, dan $(24,2 \%)$ memiliki pengetahuan kurang. Gambaran sikap responden dalam penanganan gigitan kera yaitu (21\%) memiliki sikap baik, (7,8\% cukup), dan (11,2\%) kurang. Penelitian ini diharapkan dapat menjadi data baru dalam mendukung pendidikan keperawatan khususnya dalam bidang keperawatan pariwisata, menjadi data dan bahan evaluasi bagi organisasi pramuwisata, dinas kesehatan dan pengelola wisata.
\end{abstract}

Kata Kunci: Pemandu Wisata, Penanganan Gigitan Kera, Sikap, Tingkat Pengetahuan

\begin{abstract}
Tourist visited to Ubud Monkey Forest have been very high for the past 3 years. Monkeys can bite and scratch when they feel threatened so the role of a tour guide who visits tourists to the Ubud Monkey Forest is very important in handling early monkey bite cases to prevent possible dangerous or life-threatening infections. This research is a kind of quantitative research with descriptive method. This study uses a cross sectional approach with a sample of 62 respondents obtained by purposive sampling technique. The results of the study regarding the characteristics of respondents were $(6.5 \%)$ aged $17-25$ years, $(33.6 \%)$ aged (26-35 years), (33.6\%) aged (36-45 years), (20.7 \%) aged 46-55 years, and (4.8\%) aged 56-65 years. Male gender $(100 \%)$, education in junior high school $(8.1 \%)$, high school $(54.8 \%)$, Diploma (25.8\%), undergraduate strata $(11.3 \%)$. A total of $(74.25 \%)$ received information from others, and (25.8\%) from mass media. $(6.5 \%)$ respondents had experience in handling monkey bites and $(93.5 \%)$ never. The level of knowledge of respondents in handling monkey bites was good knowledge (19.3\%), sufficient $(56.5 \%)$, and lack of knowledge $(24.2 \%)$. Descriptions of the attitude of respondents in handling monkey bites were $(21 \%)$ having a good attitude, (7.8\% enough), and (11.2\%) lacking. This research is expected to become new data in supporting nursing education, especially in the field of tourism nursing, to become data and evaluation materials for tour guides, health offices and tourism managers.
\end{abstract}

Keywords: Tour Guide, Handling Monkey Bites, Attitudes, Knowledge 


\section{PENDAHULUAN}

Gigitan kera dapat berpotensi menimbulkan beberapa penyakit seperti rabies, varicella, ebola, etetanus dan hepatitis (Kemp \& Burnett, 2003). Menurut World Health Organization (2018), gigitan kera merupakan kasus gigitan binatang tertinggi kedua setelah gigitan anjing yaitu sebanyak $2-21 \%$ pada wisatawan selama melakukan perjalanan wisata. Berdasarkan penelitian Deborah, Collen \& Philip (2011), gigitan dan cakaran hewan pada wisatawan Australia sebagian besar terjadi di Bali, Indonesia dan kasus tertinggi yaitu disebabkan oleh gigitan dan cakaran monyet/kera.

Salah satu objek wisata yang menawarkan kera sebagai daya tarik adalah Monkey Forest Ubud yang terletak di Kecamatan Ubud, Gianyar. Berdasarkan studi literatur di departemen data dan informasi Monkey Forest Ubud, terdapat 857 ekor kera tersebar di tujuh area. Keunikan tersebut menyebabkan peningkatan kunjungan wisatawan baik domestik maupun mancanegara yang mencapai 1.343.152 orang wisatawan pada tahun 2017.

Gigitan dan cakaran kera memiliki kemungkinan dapat menyebabkan infeksi jika tidak dilakukan penanganan secara cepat dan tepat. Masyarakat sering tidak melakukan pencucian dengan air mengalir melainkan sering menggunakan obat tradiosional atau ramuan herbal dalam menangani luka gigitan. Jika tidak dicuci segera dengan air mengali serta detergen kemungkinan mikroorganisme penyebab infeksi banyak yang masuk ke dalam tubuh.
Penanganan awal jika terjadi gigitan pada wisatawan dapat dilakukan secara cepat oleh orang terdekat dari wisatawan yaitu pemandu wisata yang bertugas menemani wisatawan dalam melakukana perjalanan wisata. Tingkat pengetahuan pemandu wisata berperan penting dalam penanganan awal untuk mencegah infeksi lebih lanjut.

Berdasarkan uraian di atas, maka penulis tertarik untuk meneliti gambaran tingkat pengetahuan dan sikapk pemandu wisata dalam penanganan gigitan kera di Monkey Forest Ubud mengingat wisatawan pengunjung Monkey Forest Ubud rentan terhadap risiko gigitan kera.

\section{METODE PENELITIAN}

Jenis penelitian yang digunakan adalah crosskksectional. Penelitian dilakukan selama dua minggu dan dimulai pada tanggal 26 April 2019 sampai 7 Mei 2019. Populasi dalam penelitian ini adalah orang pemandu wisata yang berkunjung ke Monkey Forest Ubud. Minimal sampel penelitian adalah 60 responden yang diperoleh menggunakan teknik purposive sampling.

Kriteria inklusi penelitian ini adalah pemandu wisata grup, individu baik wisatawan domestik, dan wisatawan mancanegara yang memiliki izin (licence) dan kartu pengenal sebagai pemandu wisata. Kriteria eksklusi penelitian ini adalah responden yang menolak atau tidak bersedia menandatangani inform consentl persetujuan sebagai responden dan responden yang tidak mengisi kuesioner secara lengkap. 
Data karakteristik responden, tingkat pengetahuan, dan sikap dalam penanganan gigitan kera diukur dari data demografi responden, 7 pertanyaan kuesioner tingkat pengetahuan dan 8 pernyataan kuesioner sikap dalam penanganan gigitan kera. Peneliti mengawali pengambilan data terhadap calon responden dengan menjelaskan prosedur penelitian, tujuan, manfaat serta hak-hak responden sebelum pengisian kuesioner. Jika calon responden bersedia menjadi menggunakan kuesioner yang disusun oleh penulis berdasarkan tinjauan pustaka. Kuesioner terdiri responden, maka calon responden diminta menandatangani lembar persetujuan menjadi responden dan mengisi kuesioner yang telah disediakan oleh peneliti kurang lebih selama 5-10 menit. Analisis data menggunakan analisis univariat untuk mendeskripsikan variabel menggunakan tabel frekuensi seperti mean, median, modus, standar deviasi, tabulasi silang.

\section{HASIL PENELITIAN}

Tabel 1 Karakteristik pemandu wisata berdasarkan usia, jenis kelamin, tingkat pendidikan, pengalaman penanganan gigitan kera, sumber informasi yang diperoleh dalam penanganan gigitan kera

\begin{tabular}{|c|c|c|}
\hline Karakteristik Responden & Frekuensi (N) & $\begin{array}{c}\text { Persentase } \\
(\%)\end{array}$ \\
\hline \multicolumn{3}{|l|}{ Usia } \\
\hline Remaja akhir (17 - 25 tahun) & 4 & 6,5 \\
\hline Dewasa awal (26 - 35 tahun) & 21 & 33,6 \\
\hline Dewasa akhir (36 - 45 tahun) & 21 & 33,6 \\
\hline Lansia awal (46 - 55 tahun) & 13 & 20,7 \\
\hline Lansia akhir (56- 65 tahun & 3 & 4,8 \\
\hline Total & 62 & 100 \\
\hline \multicolumn{3}{|l|}{ Jenis Kelamin } \\
\hline Laki-Laki & 62 & 100 \\
\hline Perempuan & 0 & 0 \\
\hline Total & 62 & 100 \\
\hline \multicolumn{3}{|l|}{ Tingkat Pendidikan } \\
\hline SMP & 5 & 8,1 \\
\hline SMA & 34 & 54,8 \\
\hline Diploma & 16 & 25,8 \\
\hline $\mathrm{S} 1 / \mathrm{S} 2$ & 7 & 11,3 \\
\hline Total & 62 & 100 \\
\hline \multicolumn{3}{|l|}{ Pengalaman dalam Penanganan Gigitan Kera } \\
\hline Pernah & 4 & 6,5 \\
\hline Tidak & 58 & 93,5 \\
\hline Total & 60 & 100 \\
\hline \multicolumn{3}{|l|}{ Sumber Informasi } \\
\hline $\begin{array}{l}\text { Media massa: televisi, radio, koran, } \\
\text { internet, brosur }\end{array}$ & 16 & 25,8 \\
\hline Orang lain/orang yang dianggap penting & 46 & 74,2 \\
\hline Total & 62 & 100 \\
\hline
\end{tabular}


Tabel 2 Distribusi frekuensi tingkat pengetahuan dan sikap pemandu wisata dalam penanganan gigitan kera

\begin{tabular}{lccc}
\hline & Variabel & Frekuensi & Proporsi \\
\hline \multicolumn{2}{l}{ Tingkat Pengetahuan Pemandu dalam Penanganan Gigitan Kera } & & \\
\hline \multicolumn{1}{l}{ Baik $(>5,94)$} & & 12 & $19,3 \%$ \\
\hline Cukup $(3,22-5,94)$ & Total & 35 & $56,5 \%$ \\
\hline Kurang $(<3,22)$ & 15 & $24,2 \%$ \\
\hline \multicolumn{2}{l}{ Sikap Pemandu dalam Penanganan Gigitan Kera } & $\mathbf{6 2}$ & $\mathbf{1 0 0 \%}$ \\
\hline Baik $(>29,46)$ & & 13 & \\
\hline Cukup $(23,74-29,46)$ & & 42 & $67,8 \%$ \\
\hline Kurang $(<23,74)$ & Total & 7 & $11,2 \%$ \\
\hline
\end{tabular}

Tabel 3 Tabulasi silang tingkat pengetahuan dengan usia, tingkat pendidikan, pengalaman dalam gigitan kera, dan sumber informasi yang diperoleh dalam penanganan gigitan kera

\begin{tabular}{|c|c|c|c|c|c|c|c|c|}
\hline \multirow[t]{3}{*}{ karakteristik } & \multicolumn{6}{|c|}{ Tingkat pengetahuan } & \multicolumn{2}{|c|}{ Total } \\
\hline & \multicolumn{2}{|c|}{ Baik } & \multicolumn{2}{|c|}{ Cukup } & \multicolumn{2}{|c|}{ Kurang } & \multirow[b]{2}{*}{$\mathrm{f}$} & \multirow[b]{2}{*}{$\%$} \\
\hline & $f$ & $\%$ & $f$ & $\%$ & $f$ & $\%$ & & \\
\hline \multicolumn{9}{|l|}{ Usia } \\
\hline Remaja akhir (17 - 25 tahun) & 1 & 25 & 3 & 75 & 0 & 0 & 4 & 100 \\
\hline Dewasa awal (26 - 35 tahun) & 4 & 19 & 9 & 43 & 8 & 38 & 21 & 100 \\
\hline Dewasa akhir (36 - 45 tahun) & 7 & 33 & 12 & 57,5 & 2 & 9,5 & 21 & 100 \\
\hline Lansia awal (46 - 55 tahun) & 3 & 18,5 & 10 & 81,5 & 0 & 0 & 13 & 100 \\
\hline Lansia akhir $(56-65$ tahun & 0 & 0 & 1 & 25 & 2 & 75 & 3 & 100 \\
\hline \multicolumn{9}{|l|}{ Tingkat Pendidikan } \\
\hline SMP & 1 & 20 & 1 & 20 & 3 & 60 & 5 & 100 \\
\hline SMA & 8 & 25 & 19 & 55 & 7 & 19 & 34 & 100 \\
\hline Diploma & 3 & 18,7 & 11 & 68,7 & 2 & 12,6 & 16 & 100 \\
\hline $\mathrm{S} 1 / \mathrm{S} 2$ & 3 & 33,3 & 4 & 66,6 & 0 & 0 & 7 & 100 \\
\hline \multicolumn{9}{|l|}{$\begin{array}{l}\text { Pengalaman dalam penanganan } \\
\text { gigitan kera }\end{array}$} \\
\hline ya & 3 & 75 & 1 & 25 & 0 & 0 & 4 & 100 \\
\hline Tidak & 12 & 19,9 & 34 & 58,4 & 12 & 21,7 & 58 & 100 \\
\hline \multicolumn{9}{|l|}{ Sumber informasi } \\
\hline $\begin{array}{l}\text { Media massa; televisi, radio, } \\
\text { koran, internet, brosur }\end{array}$ & 5 & 27,4 & 11 & 72,6 & 0 & 0 & 16 & 100 \\
\hline $\begin{array}{l}\text { Orang lain/orang yang } \\
\text { dianggap penting }\end{array}$ & 10 & 23 & 24 & 50,6 & 12 & 26,4 & 46 & 100 \\
\hline
\end{tabular}


Berdasarkan tabel 1 terlihat bahwa gambaran karkteristik umum pemandu wisata di Monkey Forest Ubud sebagian besar $(33,6 \%)$ berada pada usia dewasa awal (26-35 tahun) dan $(33,6 \%)$ berada pada usia dewasa akhir (36-45 tahun) dengan seluruh responden (62 orang) berjenis kelamin laki-laki. Mayoritas responden $(54,8 \%)$ memiliki jenjang pendidikan terakhir SMA dan sebagian besar responden $(93,5 \%)$ belum pernah melakukan penanganan terhadap gigitan kera serta informasi tentang penanganan gigitan kera sebagian besar $(74,2 \%)$ didapatkan melalui orang lain atau orang yang dianggap penting.

Pada tabel 2 pengetahuan dan sikap dikategorikan menjadi baik jika (x) > mean + 1 SD; cukup jika mean $-1 \mathrm{SD}<\mathrm{x}<$ mean $+1 \mathrm{SD}$; dan kurang jika $(\mathrm{x})<$ mean -1 SD (Riwidikdo, 2013). Nilai rata-rata (mean) untuk pengetahuan pemandu wisata yaitu 4,58 dengan standar deviasi 1,36. Berdasarkan tabel 2 dapat dilihat bahwa sebagian besar responden $(56,5 \%)$ memiliki pengetahuan cukup. Nilai rata-rata (mean) dari sikap pemandu wisata dalam penanganan gigitan kera di Monkey Forest Ubud yaitu 26,6 dengan standar deviasi 2,86 dan nilai minimum 20 dan maksimum 32. Berdasarkan tabel 2 dapat dilihat bahwa sebagian besar responden 67,8\% memiliki sikap cukup.

Berdasarkan tabel 3 tabulasi silang tingkat pengetahuan dengan usia didapatkan hasil bahwa, pada usia dewasa awal (26-35 tahun) sebagian besar responden $(43 \%)$ memiliki pengetahuan cukup, pada usia dewasa akhir (36-45 tahun) sebagian besar responden $(57,5 \%)$ memiliki pengetahuan cukup, Pada usia lansia awal (46-55 tahun) $(81,5 \%)$ memiliki pengetahuan cukup dan pada usia lansia akhir (5665 tahun) $75 \%$ memiliki pengetahuan kurang.

Tabulasi silang antara tingkat pengetahuan dengan tingkat pendidikan didapatkan hasil bahwa, tingkat pengetahuan pada responden dengan pendidikan terakhir SMP sebagian besar $(60 \%)$ memiliki pengetahuan kurang. Pada pendidikan terakhir SMA sebagian besar responden $(55 \%)$ memiliki pengetahuan cukup. Pada responden dengan pendidikan terakhir diploma sebagian besar $(68,7 \%)$ memiliki pengetahuan cukup dan pada responden dengan pendidikan strata sarjana, tidak ada responden yang memiliki pengetahuan kurang, sebagian besar $(66,6 \%)$ memiliki pengetahuan cukup.

Tabulasi silang antara tingkat pengetahuan dengan pengalaman dalam melakukan penanganan terhadap gigitan kera didapatkan bahwa, responden yang pernah memiliki pengalaman dalam penanganan gigitan kera sebagian besar $(75 \%)$ responden memiliki pengetahuan baik. Responden yang tidak pernah memiliki pengalaman dalam melakukan penanganan gigitan kera sebagian besar $(58,4 \%)$ memiliki pengetahuan cukup.

Tabulasi silang antara tingkat pengetahuan dan sumber informasi maka didapatkan bahwa responden yang pernah mendapatkan sumber informasi dari media cetak; televisi, koran, radio, internet dan brosur sebagian besar $(72,6 \%)$ memiliki pengetahuan cukup dan responden yang mendapatkan sumber informasi 
melalui orang lain/orang yang dianggap penting sebagian besar

\section{PEMBAHASAN}

Berdasarkan hasil penelitian, didapatkan bahwa sebagian besar responden berada pada kategori usia dewasa awal (26-35 tahun) dan usia dewasa akhir (36-45 tahun). Hal ini sejalan dengan penelitian yang dilakukan oleh Purnomo, Sudana dan Mananda (2016) yang menyebutkan karakteristik pramuwisata (pemandu wisata) berdasarkan usia sebagian besar berusia 36-40 tahun dan usia 41-45 tahun. Hasil penelitian Suari, Susrami dan Kusuma (2016) juga menyebutkan bahwa sebagian besar pemandu wisata berada pada usia 3039 tahun.

Berdasarkan hasil penelitian sebagian besar pemandu wisata berjenis kelamin laki-laki. Penelitian Suari, Susrami dan Kusuma (2016) juga menyebutkan bahwa sebagian besar pemandu wisata $(83,84 \%)$ berjenis kelamin laki-laki. Profesi pemandu wisata memiliki karakteristik yang dinamis, dan penuh tantangan, dimana laki-laki lebih memiliki daya tahan tubuh yang kuat dari pada wanita. Laki-laki merupakan pemberi nafkah dan penunjang utama keluarga sehingga sebagian besar pemandu wisata adalah laki-laki.

Berdasarkan hasil penelitian, sebagian besar pemandu wisata memiliki pendidikan terakhir SMA/Sederajat. Hal ini sesuai dengan penelitian Purnomo, Sudana dan Mananda (2016) yang menyebutkan sebagian besar $(55,6)$ pemandu wisata di Bali memiliki tingkat pendidikan SMA/Sederajat. Penelitian Suari, Susrami dan Kusuma (2016) juga menyebutkan bahwa sebagian besar responden
$(50,6 \%)$ memiliki pengetahuan cukup.

(56\%) memiliki tingkat pendidikan terakhir (SMA). Persyaratan menjadi pemandu wisata diantaranya adalah umur serendah-rendahnya 18 tahun, menguasai Bahasa Indonesia dan salah satu bahasa asing dengan baik dan benar, memiliki pengetahuan tentang objek wisata (Wardhani, Viverawati dan Mustafa, 2008). Berdasarkan hal tersebut, jenjang pendidikan belum menjadi syarat untuk profesi pemandu wisata.

Berdasarkan hasil penelitian sebagian besar responden belum pernah memiliki pengalaman dalam melakukan penanganan terhadap gigitan kera dimana hal tersebut dapat dipengaruhi oleh informasi mengenai penanganan gigitan kera yang masih kurang serta inisiatif dari pemandu wisata sendiri dalam mencari informasi mengenai penyakit yang terjadi di wilayah Indonesia khusunya Bali masih kurang dilihat dari jumlah pemandu wisata yang pernah memiliki pengalaman hanya 4 orang saja dari 60 responden.

Hasil penelitian menunjukan bahwa sebagian besar responden mendapatkan informasi mengenai penanganan gigitan kera melalui orang lain atau orang yang dianggap penting. Hal ini sejalan dengan penelitian Sopi dan Mau (2014) yang menyatakan pengetahuan responden cukup baik mengenai gejala, tandatanda, cara penularan, pencegahan dan pengobatan rabies dan informasi tersebut diperoleh dari kader, teman dan tetangga.

Berdasarkan hasil penelitian, tingkat pengetahuan pemandu wisata dalam penanganan gigitan kera di Monkey Forest Ubud didapatkan 
bahwa sebagian besar $(63,3 \%)$ responden memiliki pengetahuan cukup. Hal ini sejalan dengan penelitian Mohan (2015) bahwa sebagian besar responden $(48,8 \%)$ memiliki pengetahuan cukup terhadap pencegahan infeksi rabies. Penelitian Tampubolon (2016) juga menyebutkan pengetahuan sebagian besar responden $(79 \%)$ mengenai rabies berada pada katagori cukup.

Berdasarkan hasil kuesioner, sebagian besar responden tidak mengetahui lama waktu pencucian luka gigitan dan pemberian betadine atau alkohol setelah mencuci luka. Hal ini sejalan dengan penelitian Altma et al (2009) yang menyebutkan hanya sebagian kecil responden $(3 \%)$ yang mengetahui untuk segera mencuci luka gigitan serta waktu pencuciannya.

Berdasarkan tabulasi silang, pada usia lansia akhir (56-65 tahun) sebagian besar responden memiliki pengetahuan kurang. Pada usia lanjut terdapat beberapa faktor yang menyebabkan pengetahuan berkurang seperti kurangnya akses informasi di masa tersebut, kemampuan mengingat yang berkurang seiring dengan pertambahan umur serta terjadinya penurunan fungsi organ tubuh.

Berdasarkan tabulasi silang antara tingkat pengetahuan dengan tingkat pendidikan didapatkan hasil bahwa, tingkat pengetahuan pada responden dengan pendidikan terakhir SMP sebagian besar memiliki pengetahuan kurang. Menurut Notoadmojo (2012), jika seseorang memiliki tingkat pendidikan yang rendah, maka proses penerimaan, informasi, dan nilai-nilai yang diperkenalkan lebih sulit untuk diserap.
Tabulasi silang antara tingkat pengetahuan dengan pengalaman dalam melakukan penanganan terhadap gigitan kera didapatkan bahwa, responden yang pernah memiliki pengalaman dalam penanganan gigitan kera sebagian besar memiliki pengetahuan baik Menurut Notoadmodjo (2010) pengalaman secara tidak langsung berpengaruh terhadap pengetahuan dimana pengalaman adalah salah satu sumber mencari kebenaran pengetahuan .

Hasil penelitian menunjukan bahwa sebagian besar responden memiliki sikap yang cukup dalam penanganan gigitan kera. Hal tersebut sejalan dengan penelitian Tampubolon (2016) yang menyebutkan sebagian besar responden $(65,4 \%)$ mengenai rabies berada pada tingkat cukup. Hal ini dapat dilihat dari sedikitnya responden yang memiliki pengalaman dalam penanganan gigitan kera karena salah satu faktor yang mempengaruhi sikap adalah pengalaman.

Beberapa responden mengatakan jika mengalami gigitan kera atau anjing penanganan yang dilakukan secara tradisional dimasyarakat biasanya yaitu mengolesi luka dengan cabai atau arang yang besifat panas sehingga dapat membunuh virus atau bakteri penyebab penyakit. Hal ini sesuai dengan penelitan Parashar et al (2015) yang menyebutkan sebagian besar responden $(46,93 \%)$ percaya pada metode tradisional yaitu penggunaan buah cabai dalam penanganan luka gigitan binatang. 


\section{KESIMPULAN DAN SARAN}

Gambaran karakteristik umum pemandu wisata di Monkey Forest Ubud sebagian besar responden berada pada usia dewasa awal (26-35 tahun) dan usia dewasa akhir (36-45 tahun) dengan seluruh responden (60 orang) berjenis kelamin laki-laki. Mayoritas responden memiliki jenjang pendidikan terakhir tingkat SMA/Sederajat dan sebagian besar responden belum pernah melakukan penanganan terhadap gigitan kera serta informasi tentang penanganan gigitan kera sebagian besar didapatkan melalui orang lain atau orang yang dianggap penting. Gambaran tingkat pengetahuan dan sikap pemandu wisata dalam penanganan gigitan kera di Monkey Forest Ubud sebagian besar responden berada pada kategori cukup.

Hasil penelitian ini diharapkan dapat dikembangkan untuk mencari korelasi antara variabel tingkat pengetahuan dan sikap pemandu wisata dalam penanganan gigitan kera di tempat wisata lainnya. Pihak pengelola Monkey Forest Ubud dapat menyediakan sarana penanganan awal gigitan kera di area kawasan kera seperti saluran air (wastafel), sabun/detergen sehingga penanganan gigitan kera dapat dilakukan langsung oleh orang terdekat yang berada di lokasi.

\section{DAFTAR PUSTAKA}

Deborah, M. J.,, Colleen, L., Philip, W. (2011). Animal bites and rabies exposure in Australian travellers. 195 (11), 673-675.

Jakarta animal aids network. (2011). Retrieved from www.jakartaanimalaid.com

Kemenkes RI. (2016). Rabies di dunia dan di indonesia.
Kementrian Kesehatan

Republik Indonesia, 24427659.

Kemp, N.J. and Burnett, J.B. (2003). Final Report: A biodiversity risk assessment and recommendations for risk management of longtailed macaques (macaca fascicularis) in new guinea.

Notoatmodjo. 2010. Metodologi Penelitian Kesehatan. Jakarta : PT. Rineka Cipta

Notoatmodjo, S. 2012. Promosi kesehatan dan Perilaku Kesehatan. Jakarta: Rineka cipta

Parashar, P., Ahmad, S., Bansal, R., Chatoupadhaay, S., Varshney, A, M., Singh, A. Do the college students know about rabies and its prevention : a study from a university of north india. International Journal of Contemporary Medicine, 3(1), 21-26

Purnomo, D., Sudana, P., Mananda, G, P, S. (2016) pengaruh pendidikan dan pelatihan terhadap kompetensi serta dampaknya pada kinerja pramuwisata bali. Jurnal IPTA, 4(2), 52-57.

Sopi, I, I, P, B., Mau, F. (2015). Pengetahuan, sikap, dan perilaku masyarakat dalam kaitannya dengan kejadian rabies di Kabupaten Flores Timur, Sikka, Manggarai, dan Ngada, Provinsi Nusa Tenggara Timur. Journal of health epidemiology and communicable diseases 1(1), 17.

Suari, G, A, I., Susrami, G, A., Kusuma, K, G, L. (2016). eksistensi dan motivasi pramuwisata lokal perempuan 
di daya tarik wisata alas kedaton. Jurnal IPTA 4(2), 2338-8633, 48-51.

Tampubolon, S, M,. (2016). Pengetahuan, sikap, dan tindakan masyarakat Kecamatan Medan tuntungan kota medan mengenai penyakit rabies. 5-17 1(1)

Wardhani, U, E., Viverawati., Mustafa. (2008). Usaha jasa pariwisata jilid 2. Jakarta; Direktorat pembinaan sekolah menengah kejuruan
WHO. (2018). Animal bite. Diakses dari https://www.who.int/newsroom/fact-sheets/detail/animalbites

Atmann, M,. Parola, P., Delmont, J., Brouqui, P., Gautret, P. (2009). Knowledge, attitudes, and practices of french travelers from marseille regarding rabies risk and prevention. Journal of travel medicine 2009; Volume 16 (Issue 2): 107-111 